\title{
Dag Hammarskjöld's approach to the United Nations and international law
}

\author{
By Ove Bring*
}

Dag Hammarskjöld, the second Secretary-General of the United Nations, had a flexible approach to international law. On the one hand, he strongly relied on the principles of the un Charter and general international law, on the other, he used a flexible and balanced $a d h o c$ technique, taking into account values and policy factors whenever possible, to resolve concrete problems. Hammarskjöld had a tendency to express basic principles in terms of opposing tendencies, to apply a discourse of polarity or dualism, stressing for example that the observance of human rights was balanced by the concept of non-intervention, or the concept of intervention by national sovereignty, and recognizing that principles and precepts could not provide automatic answers in concrete cases. Rather, such norms would serve «as criteria which had to be weighed and balanced in order to achieve a rational solution of the particular problem» ${ }^{1}$. Very often it worked.

Professor emeritus of Stockholm University and the Swedish National Defense College. Exposición realizada en el Instituto de Estudios Internacionales el 26 de octubre de 2011.

1 Oscar Schachter, "Dag Hammarskjold and the Relation of Law to Politics», 56 American Journal of International Law (AJIL) 1962, pp. 2-5. Quotation from p. 5. Hammarskjöld recognized that there was a tension between principles and concrete needs; by taking account of both, he sought to achieve (in his own words) «that combination of steadfastness of purpose and flexibility of approach which alone can guarantee that the possibilities which we are exploring will have been tested to the full». Ibid. 
Dag Hammarskjöld has gone to history as an inspiring international personality, injecting a dose of moral leadership and personal integrity into a world of power politics. He succeeded Trygve Lie as Secretary-General in April 1953, in the midst of the Cold War, and in addition to East-West rivalry he was confronted with Third World problems and the agonizing birth of the new Republic of Congo, a tumultuous crisis through which he lost his life in the Ndola air crash in September 1961.

\section{INTELLECTUAL BACKGROUND AND PERSONAL PHILOSOPHY}

Dag Hammarskjöld was born in 1905 in a small town in middle Sweden where his father at the time was President of the District Court of Appeal. His father, Hjalmar Hammarskjöld, was later, between 1914 and 1917, Prime Minister of Sweden. Dag's elder brother Åke became in 1920 a member of the League of Nations secretariat. Between 1922 and 1936 Åke was Registrar of the Permanent Court of International Justice in the Hague. At the time of his premature death, in 1937, Åke was appointed to serve as a Judge in the Hague Court. The father and his sons were groomed in a typical Swedish civil service tradition where the concepts of «duty» and «responsibility» reflected time-honored values. It has been said of Dag Hammarskjöld that he had a manifest pride in his family's legal background and that he «regarded himself as a man of law». ${ }^{2}$ Nevertheless, he was a professional economist. Although he studied law at Uppsala University he later produced a doctoral thesis in economics.

Dag had a very close relationship to his mother Agnes, a religious and pious woman, and from her he inherited a simple wish to «do good» in concrete cases. Already as a young man he was interested in medieval religious thinking. His early correspondence includes references to mystics like Meister Echart (d. 1327) and Thomas a Kempis (d. 1471). He had received Thomas a Kempis'De imitatione Christi from his

2 Gustaf Aulén, Dag Hammarskjöld's White Book, An Analys of Markings, Fortress Press/Gleerup, Philadelphia 1969, p. 14. 
mother Agnes in 1921 and kept the book for the rest of his life. Later he also referred to Thomas Aquinas (d. 1274), the more empiric and realist philosopher who tried to combine Christian doctrine with Aristotelian thinking, and St. John of the Cross (d. 1591), who combined Christian mysticism with religious reformism and poetry. What these thinkers had in common was a focus on meditation and seclusion, a stress on the importance of a man's inner life in relation to God in preparation for individual choices and individual action. Hammarskjöld was through his life attracted to this personal approach to moral decision-making. It also connected to then societal values of «duty, righteousness and self-service»conveyed by his father and pious-moral influence exerted by his mother. ${ }^{3}$

Hammarskjöld also had an intense relationship to world literature. He used the works of Joseph Conrad, Herman Hesse, Fjodor Dostojevskij and others for personal reflection in situations where decisions needed to be taken. It was manifest from his correspondence and diary that these and other authors played a significant role in his world of ideas. Dostojevskij's The Brothers Karamazov includes references to each individual's universal responsibility for other individuals, to the ideas of «service to mankind» and «brotherhood and inclusiveness of men», and to individual action «for the sake of future». Hammarskjöld was much attracted to the idea of moral individual action. He also felt that Joseph Conrad's book Lord Jim and Herman Melville's Moby Dick caught the dilemmas of strong-willed individuals who pursued their chosen path of life in constant uphill battles.

Hammarskjöld was not afraid of uphill battles. He saw the appointment as Secretary-General to the UN as a challenge and a chance to be of real service to the international community. He was much influenced by the ethics of Albert Schweitzer and his emphasis on the sanctity of human life. At last Hammarskjöld was himself in a position to put into action the ideal of service to man.

"An International Administrative Service», from an address to the International Law Association at McGill University, Montreal, 30 May, 1956. See Wilder Foote (Ed.), The Servant of Peace, A Selection of the Speeches and Statements of Dag Hammarskjöld (hereinafter referred to as Speeches), The Bodley Head, London 1962, p. 116. 


\section{IN THE United Nations}

Already some time after Hammarskjöld's appointment as Secretary-General in 1953 it became clear that he had an innovative approach to the possibilities of the United Nations. He was not a formalist, he wanted to go forward and act in line with the purposes of the UN Charter. The purposes of the Charter were fixed and binding, but the working methods of the Organization must be flexible and innovative. He did not want to feel fettered by concrete provisions of the Charter that did not explicitly provide for things he wanted to do, options he wanted to test in his capacity as Secretary-General. If he felt that the purposes of the UN made it possible, he would envision a mandate flowing from the Charter to act in accordance with his conscience as an international civil servant.

Hammarskjöld set out his views on the role of the UN Organization and his approach to the UN Charter in the Annual reports to the General Assembly. In this context he developed a doctrine on the independence of the international civil servant, including an active role for the Secretary-General under an expansive interpretation of Articles 97-100 of the Charter. He introduced new mechanisms for a UN presence in conflict areas, for example the appointment of Special Representatives of the Secretary General (SRSG:s).

He did not make a very sharp distinction between law and politics. He did not look upon international law as mainly "written law", but emphasized the whole international pattern of rules and behavior. Already before Wolfgang Friedman had published his famous book The Changing Structure of International Law (1964) Hammarskjöld used the distinction between the traditional «law of coexistence» and the more dynamic «law of cooperation». The world, in his view, was slowly moving into the latter more advanced area, which included supranational decision-making.

During his time as Secretary-General (1953-61) Hammarskjöld set forth a number of general themes regarding the role of the un, but he did not articulate specific doctrines on human rights, intervention or security. Nevertheless, as we shall see, he developed new methods for the functioning of the system 
of collective security, and he was a forerunner in the field of what today is called human security.

One of Hammarskjöld's first tasks as Secretary-General was to negotiate the release of American pilots taken prisoners by China in the aftermath of the Korean War. In this context he felt the support of the wisdom of the Jewish philosopher Martin Buber as expressed in the book Ich und Du (1923). Buber stressed the importance of human dialogue and Hammarskjöld's visit to Beijing in January 1955 was marked by fruitful intellectual dialogue with Chinese Premier Chou En-lai. The chemistry between the two men made the conversation sparkle. Later the same year the US airmen were released. The release coincided with Chou En-laís personal congratulations to the Secretary-General at his $50^{\text {th }}$ birthday. Hammarskjöld is famous for having coined the concepts of preventive and quite diplomacy, but in this case it was more a matter of personal diplomacy.

\section{THE INTRODUCTION OF PEACEKEEPING}

Hammarskjöld is best known for his innovative approach to the UN Charter. The first example here is the matter of peacekeeping, which was not, and still is not, mentioned in the Charter.

Hammarskjöld elaborated the new concept during the Suez crisis of 1956. As the Security Council was blocked by a joint British and French veto the Secretary-General had to rely on the General Assembly. As a procedural matter he used the Uniting for Peace resolution of 1950 to summon an extra Emergency Session of the Assembly. Together with the Canadian Foreign Minister, Lester Pearson, he thereafter introduced the option of a UN mandated military peace operation in the conflict area, with the consent of the parties to the conflict. On 7 November, 1956, the General Assembly adopted a resolution which launched the first peacekeeping operation in UN history, the UN Emergency Force in the Middle East (UNEF).

Although Un observer missions had been fielded in 1948 and 1949, the deployment of armed troops to assist in the implementation of agreements reached between the UN and 
parties to a conflict added a new dimension to international relations. To govern these operations Hammarskjöld laid down three principles: (1) consent from the territorial state and other parties involved; (2) impartiality from the un side to secure credibility in the operation; and (3) non-use of force from the un side, unless in individual self-defense or collective mission defense.

Over the years it became clear that the Security Council should be the Un body to decide on all forms of un peace operations, not only with regard to peace enforcement under Chapter vil of the Charter, but also with regard to cooperative peacekeeping.

When UNEF was established Hammarskjöld considered it a new departure. "It is", he said, "certainly not contrary to the Charter, but is in a certain sense outside the explicit terms of the Charter».

Thus peacekeeping operations, PKOs, were not foreseen under either Chapter VI or VII of the Charter, they fell somewhere in between, and not surprisingly the unwritten Chapter $\mathrm{VI} 1 / 2$ has been suggested as their legal basis. It is submitted that this «VI $1 / 2$ perception» is appropriate and useful; appropriate because PKOs are a more ambitious involvement than anything provided for in Chapter VI; and politically useful because it shows that innovations, even without textual support, can be legitimized under the system of the Charter if they fulfill the purposes of the UN Organization.

\section{HAMMARSKJÖLD'S DYNAMIC APPROACH TO THE LAW OF THE UN}

Dag Hammarskjöld was appointed Secretary-General five years after Hans Morgenthau had published his influential realist opus Politics among Nations. In a speech in 1956 Hammarskjöld had reason to comment on the divide between idealism and realism. Assertions that the un had failed were often misleading, he said:

Do we refer to the purposes of the Charter? They are expressions of universally shared ideals which cannot fail us, though we, alas, often fail them. Or do we think of the institutions of 
the United Nations? They are our tools. We fashioned them. We use them. It is our responsibility to remedy any flaws there may be in them.

And he continued:

This is a difficult lesson for both idealists and realists, though for different reasons. I suppose that, just as the first temptation of the realist is the illusion of cynicism, so the first temptation of the idealist is the illusion of Utopia. ${ }^{4}$

Hammarskjöld was an idealist in the sense that he believed in the purposes and principles of the UN Charter and in the possibilities of the UN Organization. At the same time, he was a realist in the sense that he did not want to stretch the potential capacities of the Organization too much if member states were not ready for it. For example, he opposed the idea of a standing UN military force, because he felt it was politically premature in view of the strong feelings related to national sovereignty, and also because he felt it was unpractical to have a ready-made military unit standing by, when it was much better to tailor a unit to the specific demands of an upcoming situation. ${ }^{5}$

It goes without saying that he wanted the UN to respond to the demands of the international community, and in reflecting how that should be done he fell back on a distinction between existing legal norms and innovative procedures. On the one hand, he could refer to the un normative framework in a natural law oriented manner that included an implicit element of staticism. Thus, in 1956 he stated that

the principles of the Charter are, by far, greater than the Organization in which they are embodied, and the aims which they are to safeguard are holier than the policies of any single nation or people. ${ }^{6}$

4 Brian Urquhart, Hammarskjold, The Bodley Head, London/Sydney/ Toronto 1973, p. 230.

5 Statement during the Suez Crisis, October 31, 1956. Official Records of the Security Council, 751 $1^{\text {st }}$ meeting. Quoted in Urquhart (1973), p. 174.

6 From the Introduction to the Annual Report of the Secretary-General on the Activities of the Organization 1958-59, 22 August, 1959. Speeches (1962), p. 223. 
On the other hand, he often used a dynamic and evolutionary approach to the system of the UN Charter, arguing for example that although the objectives and rules of the Charter were binding, the working methods of the system could be supplemented by new procedures:

As is well known, such an evolution has in fact taken place, and it has ... been recognized that ... new procedures may be developed when they prove productive in practice for ... the objectives of the Charter. In this respect, the United Nations, as a living organism, has the necessary scope for a continuous adaptation of its ... [system] to the needs [of the international community.$^{7}$

This organic approach was in line with his views on the Uniting for Peace resolution and the establishment of UNEF. But Hammarskjöld developed it further into a dynamic conception of the UN Organization. His successor, U Thant, once remarked that Hammarskjöld was prone to use his great gift for innovation and improvisation. He "discovered new ways to help keep the peace» - an emergency force in one situation, an observer group in another, and a UN presence in a third context. ${ }^{8}$

The dynamic approach of Hammarskjöld was also stressed by his collaborator in the UN Secretariat, Ralph Bunche. Bunche indicated in a speech in 1964 that Hammarskjöld consciously strove to make the UN a progressive force for human advancement. Wherever there was a conflict situation, actual or threatening, he believed the UN should actively seek to contain or avert it:

[B]y quiet diplomacy when the circumstances permitted, in the form of good offices if the parties themselves demonstrated an inability to deal with the situation; and, if necessary by overt United Nations action.

Bunch added that Hammarskjöld saw clearly that the UN «must do more than hold meetings and talk and adopt

7 U Thant, «Looking ahead», Address given at Columbia University, January 7, 1964. See Andrew N. Cordier and Wilder Foote (Eds.), The Quest for Peace, The Dag Hammarskjöld Memorial Lectures, Columbia University Press, New York \& London 1965, p. 40.

8 Quotation by Lester B. Pearson in Cordier \& Foote (1965), p. 100. 
resolutions». ${ }^{9}$ Hammarskjöld said himself at a press conference, early in 1959, that the UN simply must respond to those demands which may be put to it. If those demands would go beyond the "present capacity", that must not, in itself, be a reason to exclude action. The capacity of the un could prove to be bigger than expected. He referred to the Organization as a machine, thrusting its way through the terrain of international politics. He said:

I do not know the exact capacity of this machine. It did take the very steep hill of Suez; it may take other and even steeper hills. $^{10}$

Hammarskjöld was not confronted with the issues of human security and UN intervention until the summer of 1960, but he had reason to comment upon some of the elements of that discourse before that. With regard to the protection of national sovereignty he referred in a speech in 1953 to the classical Chinese philosopher and poet Tao-Tse Tung, who is reported as stating that whoever wants to grip the world and shape it will fail, because the world is a spiritual thing that cannot be shaped. Hammarskjöld later in his speech made clear that the United Nations

has no power to encroach upon the national sovereignty of any state against the will of its government and people. It would indeed not only be against the letter and the spirit of the Charter ... to attempt to impose its will in domestic matters. It would also be against the elementary wisdom expressed . . . [by] Tao-Tse Tung. ${ }^{11}$

With regard to the protection of human rights Hammarskjöld said at one point that behind the Universal Declaration of Human Rights "we find literally thousands of people who directly or indirectly participated actively in its drafting». ${ }^{12} \mathrm{He}$ thereby implied that the Declaration was not mainly a contribution of the West. He further stated that the Declaration

\footnotetext{
$9 \quad$ Speeches, Wilder Foote (1962), p. 43.

10 "The Uses of Private Diplomacy», Address in the Houses of Parliament, London, 2 April 1958. Speeches (1962), p. 174.

11 Unpublished statement quoted by Brian Urquhart in Hammarskjold (1973), p. 438.

12 Ibid., p. 438.
} 
could be called a "universal expression» on the subject in a world where the memory was still fresh of some of the worst infringements of human rights ever experienced in history.

With regard to the principle of collective security Hammarskjöld sometimes referred to the Chapter viI procedure as a necessary requirement for armed action. At the same time he was prone to relate the matter of collective peacemaking to the other objectives of the Charter. Not surprisingly, he then used a contextual approach. In his view, peace was not solid without human rights, and human rights could not be fully realized unless peace was at hand. ${ }^{13}$

In a similar tenor he also saw the creation of the UN as something going beyond the exclusive interests of states and governments. In 1968 he made the point that a global cooperative project was not a new idea. The un Organization was a body for collective efforts established after centuries of human struggle. He said:

It is the logical and natural development from lines of thought and aspiration going far back into all corners of the earth since a few men first began to think about the decency and dignity of other men. ${ }^{14}$

The choice of emphasis on «men» instead of «states», and on «dignity» instead of security, is perhaps telling for how Hammarskjöld regarded the objectives of the un Charter. Collective security included human dignity. Or, as we would express it today, collective security is not only state security but also human security. The interests of the international society of states could and should not differ from the interests of mankind.

\section{THE ISSUE OF UN HUMANITARIAN INTERVENTION IN PEACE OPERATIONS}

When the political situation in the Republic of Congo deteriorated in the summer of 1960 a un peace operation was

13 Security Council Official Records, 896th Meeting, 9 September 1960, para 101.

14 "The Uses of Private Diplomacy", Address in the Houses of Parliament, London, 2 April 1958. Speeches (1962), p. 174. 
launched, ONUC. In August there were tribal massacres in the province of Kasai. Hundreds of Balubas were killed by Government soldiers. Villages had been pillaged and burned and their inhabitants, including children, killed simply for the reason of their ethnicity.

Hammarskjöld felt -and made clear to his associates- that the UN could not stand aside and remain passive in what he called «a case of incipient genocide». He indicated that the Central Government had to accept this responsibility of the UN.

True, the Kasai situation was a delicate one for the UN to interfere in, against the background of an unclear mandate and the non-intervention principle of Article 2(7) of the Charter. But, on the other hand, Hammarskjöld concluded in a cable to his emissary in Leopoldville:

Prohibition against intervention in internal conflicts cannot be considered to apply to senseless slaughter of civilians or fighting arising from tribal hostilities. ${ }^{15}$

After a meeting with his advisers in New York, he authorized the interposing of UN troops, using force if necessary, to stop the massacres. ${ }^{16}$ As it happened, in the beginning of September 1960, the situation calmed down and there was no need to act upon these instructions.

In reporting to the Security Council on 9 September Hammarskjöld referred to the atrocities as international crimes. He stated:

They involve a most flagrant violation of elementary human rights and have the characteristics of the crime of genocide since they appear to be directed towards the extermination of a specific ethnic group, the Balubas. ${ }^{17}$

Hammarskjöld did not at this point ask for an extended ONUC mandate to deal with the humanitarian threats. His moral gut reaction was -as is shown by the cable to Leopoldville- that it was not necessary. But diplomatic prudence would of course have it that any humanitarian crossing of

15 Unpublished statement quoted by Brian Urquhart in Hammarskjold (1973), p. 438.

16 Ibid., p. 438.

17 Security Council Official Records, 896th Meeting, 9 September 1960, para 101. 
the borderline between peacekeeping and peace enforcement should be mandated by the Security Council, and if there is no time for that, that Council approval should at least be registered ex post facto.

Hammarskjöld's position in principle was clear. We can assume that it was not exclusively a legal position. His moral «do good» inclination was probably influenced by his Christian values and he was not prepared to compromise with his personal conviction. In his report to the General Assembly he made clear:

You try to save a drowning man without prior authorization. ${ }^{18}$

There was probably also a policy element of human rights involved. Hammarskjöld was normally not a driving force in the field of human rights. The issue was tainted with Cold War controversy and he regularly approached it with caution. In this case, however, he was prepared to use the Secretary-General's power of interpretation to protect human rights and play the card of «incipient genocide» to increase his power of persuasion. To him, obviously, it was a matter of values and a mix of law and morality. He was not alien to the incorporation of extra-legal elements in the process of international law. Although he laid heavy emphasis on the non-intervention principle of Article 2(7) of the Charter, he nevertheless thought that the Kasai massacres were outside the scope of that provision. His personal ethics coincided with the natural law proposition that lex scripta had to be reconciled with a law of higher order.

Hammarskjöld's policy related instinct, focused on a kind of «UN responsibility to protect» perception, did not make a significant imprint in the peacekeeping discourse during the Cold War. It is noteworthy, though, that the principle of protecting civilians during peace operations has been brought into the present millennium by the Brahimi report $(2000)^{19}$ and through the broader concept of Responsibility to Protect

18 Statement on UN Operations in Congo before the General Assembly, 17 October 1960.

19 Report of the Panel on United Nations Peace Operations, chaired by Ambassador Lakhdar Brahimi (Algeria), transmitted to the Secretary-General on 17 August 2000. UN Doc. A/55/305-S/2000/809. 
$(2005)^{20}$. Hammarskjöld's instinctive approach to the matter has come to stay and is now codified in the peacekeeping doctrine of the United Nations. ${ }^{21}$

\section{CONCLUDING REMARKS: LEADERSHIP AND LEGAL DEVELOPMENT}

The future of the UN Organization lies, as always in the case of Inter-Governmental Organizations (IGOs), in the hands of Member States. Political will is essential, as is international leadership. Unfortunately, the world today suffers from a lack of both. As to political will, Hammarskjöld did not expect it to surface in multilaterally negotiated documents, he saw it develop through precedents created by a responsible international leadership. Thus the Hammarskjöld approach to the unand international law was not to rely on drawn out political compromise, but on ad hoc arrangements responding to urgent and concrete needs in line with the purposes of the UN. As Hammarskjöld's biographer Brian Urquhart has pointed out, the then Secretary-General believed that a just and reliable world order had to rely on precedents (state practice) made possible through political acquiescence. In that sense he was a political realist.

Hammarskjöld's contribution to international law, beyond his innovative and flexible use of the UN Charter, lies in his emphasis on value based collective decision-making in response to pressing needs. He realized that a progressive development of international law could not exclusively be achieved through multilateral treaty-making, but that, in addition, an element of development through practice would be needed. However, development through precedents presumes that those international actors which are prepared to take the lead, statesmen of governments and organizations, can inspire confidence in their initiatives vis-à-vis the rest of the international community.

20 General Assembly Resolution 60/1, World Summit Outcome Document (2005), paras 138-139.

21 Report of the Secretary-General, Implementation of the Recommendations of the Special Committee on Peacekeeping Operations, UNDoc. A/60/640 (2005). 
To find and promote such actors of global leadership, sensitive to political feelings and aware of political opportunities, with distinct trans-cultural outlooks, will be a challenge for nation-states and international organizations alike. Statesmen of the caliber of Dag Hammarskjold are hard to find.

Thank you. 